\title{
1. General introduction: issues in Africa's efforts to protect the rights of minority groups
}

\subsection{INTRODUCTION}

How to guarantee the peaceful coexistence of all population groups in divided societies and provide necessary legal mechanisms for the effective protection of the fundamental rights of minorities (e.g., minority ethnic and religious groups) has haunted African countries since they gained independence from the European colonizers and emerged as sovereign nations in the 1950s and 1960s. Today, the failure or inability of many African countries to adequately and effectively manage ethnocultural diversity and provide institutional environments and governing processes capable of fostering peaceful coexistence, national integration, and nation-building, is one of the most intractable governance problems currently facing the continent. Such a failure has produced economies that are or have been pervaded by extremely high levels of political violence, most of it attributable to destructive mobilization by ethnic and/or religious groups that consider themselves marginalized, pushed to the political and economic periphery, summarily denied the opportunity to participate gainfully in post-independence wealth creation and economic growth, and/or granted an inferior type of citizenship/nationality (i.e., one that does not allow them to participate fully and effectively in political and economic markets). These economies are currently not able to guarantee the peaceful coexistence necessary to maximize the creation of the wealth that they need to deal effectively and fully with poverty and material deprivation.

The rights that we talk about in this book include, but are not limited to, those contained in the United Nations' Universal Declaration of Human Rights (UDHR) and other international human rights documents (e.g., the International Covenant on Civil and Political Rights and the International Covenant on Economic, Social and Cultural Rights). Citizens of a country may define and elaborate additional rights in their constitutions, as long as such provisions reflect generally accepted 
principles of fundamental rights such as those elaborated in the UDHR and other international human rights treaties (Konvitz, 2001; Suresh, 2010).

The struggle, by groups that perceive themselves as marginalized and deprived and forced to remain permanently in the opposition by a central government that is dominated by other groups, has produced a lot of violence in Africa. Consider, for example, the fact that during the last several decades, countries such as Liberia, Sierra Leone, Nigeria, Rwanda, the Republic of Sudan, Democratic Republic of Congo, Ethiopia, Côte d'Ivoire, Burundi, Central African Republic, Egypt, and South Sudan, have been embroiled in some form of violent and brutal conflict induced by mobilization by ethnic and/or religious groups. In virtually all of these cases, the violence has produced significant losses in terms of human lives and property. In addition to the extraordinary loss of human capital through death, dismemberment, malnutrition, internal displacement, disease, and forced migration, many of these economies have been rendered, even if only in the short run, incapable of engaging in productive activities to create jobs and produce the wealth needed for effective poverty alleviation efforts. While some of these economies have since recovered (e.g., Rwanda) and are currently making positive improvements in their productive capacities, others (e.g., Democratic Republic of Congo and South Sudan) remain embroiled in violent mobilization by groups that believe that the central government is dominated and controlled by their enemies and that the only way to improve their lot in life is to forcefully capture the state (see, e.g., Straus and Waldorf, 2011; Human Rights Watch, 2009; Gberie, 2005; Williams, 2002; McGovern, 2011; Uwechue, 2004).

Examples of ethnocultural groups that have been engaged in destructive and violent mobilization to assert their rights include (1) the Igbos of Nigeria, who, together with a collection of minority ethnic groups in southeastern Nigeria, fought a brutal and extremely violent civil war from 1967 to 1970 to separate from the Federal Republic of Nigeria and form their own sovereign nation; (2) various "indigenous" ethnic groups in Liberia, led by Sargent Samuel K. Doe's Krahn ethnic group, which fought a bloody war to dismantle the more than 100-year old minority Americo-Liberian hegemony and introduce a democratic dispensationof course, the Doe-led government that emerged from the civil war did not introduce such a democratic dispensation; instead, the regime became a worse violator of human rights than all previous governments combined; (3) the Anglophones of Cameroon-although they have never engaged in any violent mobilization, they have nevertheless, continued to protest against what they believe is marginalization and infantilization at 
the hands of the Francophone-dominated central government in Yaoundé; and (4) the Hutu of Rwanda, who in 100 days of a murderous rampage, killed as many as 800,000 of their fellow Tutsi brethren and their Hutu sympathizers. Of course, this list is not exhaustive. Throughout the continent, many ethnocultural groups, which consider themselves marginalized economically and politically, continue to opt for violent and destructive mobilization in order to improve their levels of participation in economic and political markets and minimize further marginalization.

The failure of African countries to manage ethnocultural diversity effectively and guarantee the peace that is a sine qua non for entrepreneurs to voluntarily invest in productive capacity has had a significantly negative impact on wealth creation and economic growth in these countries since they gained independence. For, without peace, it is virtually impossible to attract the investment (both foreign and domestic) needed to create wealth - continued political and economic instability has exacerbated capital flight and endangered economic growth and development (see, e.g., Ajayi and Khan, 2000). The continent's failure to deal fully and effectively with the challenges posed by ethnocultural diversity can easily be seen in countries such as Central African Republic, Democratic Republic of Congo, Liberia, Nigeria, Rwanda, and Sierra Leone, which during most of the post-independence period, have encountered significant levels of ethnic-induced political violence, some of which has resulted in brutal and prolonged civil wars.

Throughout Africa, many minority ethnocultural groups have argued that post-independence governance systems are dominated by a majority that has relegated the minorities to the political periphery, where they are expected to serve as a permanent and inconsequential opposition. While the majority elites have used the apparatus of state to enrich themselves and their benefactors, minorities remain impoverished and suffer from significantly high levels of material deprivation. For example, in a State of the Nation speech delivered to the people of the secessionist Republic of Biafra on 1 June 1969, then leader of the break-away southeastern region of Nigeria, Colonel Emeka Ojukwu, accused the Nigerian nation of killing its own citizens. He stated that "Nigeria persecuted and slaughtered her minorities; Nigerian justice was a farce; her elections, her census, her politics - her everything-was corrupt."1

Colonel Ojukwu went on to state that Nigeria's public sector, including especially its civil service, practiced significant levels of employment discrimination. He argued that "[q]ualification, merit and experience were discounted in public service" and that "a university Vice-Chancellor was sacked because he belonged to the wrong tribe." 2 
The Igbos and other minority groups from the Eastern Region of Nigeria believed that the national government was dominated by a coalition, even if ad hoc, of the Hausa-Fulani and Yoruba ethnic groups and that public policies in the Federal Republic of Nigeria were being used systematically and effectively by this majority to discriminate against and marginalize minority ethnocultural groups within the federation. In fact, as argued by the leader of the country's eastern provinces, the various ethnocultural groups that inhabited Eastern Nigeria no longer felt that the Nigerian Government was capable of or willing to protect their persons and property. Public policies, these groups believed, had relegated them to the political and economic periphery, where they were left to fester in poverty and deprivation. As stated by Col. Ojukwu, these and other issues were the reasons why Eastern Nigeria decided to secede and form a sovereign independent nation (Uwechue, 2004; Uzokwe, 2003; Forsyth, 2007). ${ }^{3}$

Nigeria is not the only African country with significant levels of ethnocultural diversity which, during the post-independence period, has encountered violent and destructive ethnic mobilization. In Cameroon, the Anglophones have, since 1972, when the Francophone-dominated federal government in Yaoundé abrogated the federation and effectively eliminated all the protections that were granted the English-speaking minority by the federal constitution, complained of economic and political marginalization at the hands of their politically-dominant Francophone brothers and sisters. Some Anglophones have called for secession and formation of their own sovereign nation (Konings and Nyamnjoh, 1997, 2004).

Other African countries with divided societies that have encountered ethnoculturally-induced destructive and violent mobilization during the last few decades include, but are not limited to, Democratic Republic of Congo, Côte d'Ivoire, Kenya, Liberia, Sierra Leone, and Sudan. Most of the mobilization by subcultures to improve their participation in political and economic markets and arrest further marginalization has resulted in brutal civil wars that have killed many people and destroyed a lot of property (Mutwol, 2009; Kieh, 2008; Mamdani, 2002; Johnson, 2003; Turner, 2007).

Countries such as Kenya, that have historically been considered peaceful and well-governed, have suddenly found themselves embroiled in violent and destructive mobilization by ethnocultural groups, some of it involving mass murder and the destruction of a significant amount of property, as well as the displacement of many people from their homes and the creation of a major humanitarian crisis (Njogu, 2009; Materu, 2015). The overriding problem is that the majority of African countries 
are divided societies-countries that are characterized by significant levels of ethnocultural diversity. A country like South Sudan, for example, has about 60 ethnic groups. Since independence from the Republic of Sudan in 2011, political economy in the country has been dominated by the Dinka (38.8 percent) and the Nuer (27.6 percent), the two largest groups, and in the process, other groups have been totally marginalized, both politically and economically. At independence on 9 July 2011, Riek Machar, a Nuer, became vice president and Salva Kiir, a Dinka, assumed the position of the president of the new country. However, on 23 July 2013, Dr. Machar was sacked by President Kiir and the former and his Nuer supporters opted for violent mobilization to either recapture their position in the executive branch of government or carve out part of the country, especially that which contained the country's enormous oil reserves, for themselves. The result of the mobilization by Dr. Machar and his supporters was an extremely bloody civil war that started in December 2013. Thus, since independence, South Sudan has not been able to deal effectively and fully with the challenges posed by ethnocultural diversity.

A peace agreement was signed on 26 August 2015, paving the way for the establishment of a Transitional Government of National Unity (TGoNU), which was expected to govern the country for two and a half years, pending elections to establish a permanent government. The TGoNU, with Dr. Machar as vice president and Mr. Kiir as president, was sworn in on 26 April 2016. Despite these developments, many of the country's minorities continue to feel that they are being marginalized by what they see as a permanent Dinka-Nuer hegemony.

\subsection{ETHNICITY AND VIOLENT MOBILIZATION}

Virtually all African countries are ethnically diverse. The problem of pervasive political violence in the continent, however, is not caused by the existence of ethnocultural diversity per se, but by the inability or unwillingness of national governments to effectively manage diversity and create, within their countries, institutional arrangements that allow all groups to maximize their values (e.g., preserve their customs and traditions) and compete fairly for the benefits of post-independence economic growth. Part of the problem can be traced to the failure of many African countries to provide themselves with institutional arrangements that guarantee the rule of law. The 2007/08 post-election experiences of Kenya can be used to illustrate this point. 
Following presidential elections in Kenya in December 2007, ethnicinduced riots consumed the country and resulted in the massacre of more than a thousand people and the destruction of significant amounts of property. In fact, within six weeks of the inauguration of Mwai Kibaki as President of the Republic of Kenya - the incumbent who had been declared the winner of the December 2007 presidential elections-1000 people across the country had been hacked to death and as many as 50,000 others had been violently chased away from their homes and property (see, e.g., Njogu, 2009).

Kenya's post-election violence exposed significant weaknesses within the country's institutional arrangements. The main contestants in the December 2007 elections in Kenya were Mwai Kibaki, an ethnic Kikuyu and the incumbent, and Raila Odinga, an ethnic Luo and leader of the opposition. After the elections were completed but before the official results could be released, Odinga and his supporters-mostly ethnic Luo-accused Kibaki of fraudulently manipulating the results to his advantage and that of his Kikuyu benefactors. The two political leaders subsequently engaged in negotiations to resolve the issue of who had actually won the election and hence, determine who would be president. However, before a solution acceptable to both parties had been achieved, Kibaki unilaterally declared himself the winner of the election. Shortly after that declaration, violence erupted in many parts of Kenya - the violence involved, on one side, supporters of Kibaki, who were mostly ethnic Kikuyu, and on the other side, those of Odinga, who were mostly Luo and Kalenjin. The violence soon degenerated into a form of ethnic cleansing in which thousands of people lost their lives and as many as 600,000 people lost their homes and property (Njogu, 2009).

The Rift Valley of Kenya, where a significant amount of the violence took place, is populated by large enclaves of Kikuyu. However, the Kalenjin consider this part of the country to be their ancestral lands. Most of the people who were killed in this area and their properties either seized or destroyed were ethnic Kikuyu. It was generally understood that the massacre of Kikuyus by marauding gangs of Kalenjin and Luo youth, was in retaliation for the decision by incumbent president, Kibaki, an ethnic Kikuyu, to deprive the Luo and Kalenjin of the opportunity to capture the presidency (see, e.g., International Crisis Group, 2008).

In Spring 2013, Kenya held new presidential elections, which were won by Uhuru Kenyatta (President) and William Ruto (Vice President). Since Kenyatta is Kikuyu and Ruto is Kalenjin, students of Kenyan political economy believed that the capture of the apparatus of government by both the Kikuyu and Kalenjin is evidence that ethnic tensions have, since the post-election violence that gripped the country in late 
2007 and early 2008, abated. However, in the Rift Valley, the inter-ethnic clashes that produced the massacre of many Kikuyus, as well as the destruction of a significant amount of property, remain fresh in the minds of many people, especially in those of the thousands of Kikuyus who were displaced and continue to languish in refugee camps. Despite the institutional reforms that have taken place in Kenya since the December 2007 post-election violence, the country has not yet provided itself with necessary mechanisms for effective management of ethnocultural conflict, especially that associated with, or arising from, the struggle to capture positions in the government. The ethnic group remains the foundation for political competition; ethnic political parties continue to dominate politics; and successful national politicians are expected by their ethnic groups to represent them and not the nation as a whole. As a consequence, it is very difficult for political parties to develop platforms that appeal to the median voters. Instead, most political competition is based on appeals by candidates to members of their ethnic groups for the votes that they need to win. Such an approach to political competition favors primarily large ethnic groups and disadvantages minorities.

\subsection{INDEPENDENCE AND THE HOPE FOR PEACEFUL COEXISTENCE}

Africans, especially those who led the fight against colonialism, saw independence as an opportunity to introduce and sustain a new governance architecture, especially one that would place decision making about political and economic governance in the hands of Africans (Mbaku and Ihonvbere, 2003). As argued by Mbaku and Ihonvbere (2003: 2),

[m]any Africans ... believed that independence was an opportunity to rid themselves of not only the Europeans, but also of their laws and institutions and then, develop and adopt, through a democratic process (i.e., a peopledriven, bottom-up, participatory, and transparent institutional reform process), institutional arrangements based on their own values, aspirations, traditions, and customs.

Within such a new post-independence dispensation, the new Africancentered State would make maximizing the welfare of Africans (not that of the Europeans) the most important objective of public policy. Hence, the post-independence state was expected to pursue policies that enhanced the peaceful coexistence of all population groups within the country - the state would dismantle and dispose of those structures and mechanisms installed by the colonialists to force each colony's various 
peoples to coexist peacefully and instead, develop laws and institutions, through a democratic process, that would adequately constrain the government but allow the various population groups in each country to live together peacefully and maximize their values without infringing on the ability of others to do the same. Thus, each ethnocultural group would be granted a significant level of autonomy so that it could pursue its values and interests but do so within the legal and political boundaries or constraints agreed to in an earlier period and elaborated in the constitution (Mbaku, 1997). A strong and competent government, one that is granted enough power to perform its constitutionally-assigned functions, but is also adequately constrained so that it would not be the source of tyranny directed at the people, would be formed to enforce the laws, develop and implement policies to promote the common good, and protect the fundamental rights of the people - there would neither be a dictatorship of the majority (e.g., the Francophones in Cameroon) nor of the minority (e.g., the Americo-Liberian minority in Liberia or the white apartheid government in pre-1994 South Africa).

In the post-independence economy, individuals and groups could mobilize to create wealth but such activities were not expected to involve violence or deteriorate into destructive conflict since the laws and institutions adopted earlier were supposed to provide effective mechanisms (e.g., well-defined and enforced property rights; separation of powers, with effective checks and balances; a professional civil service, etc.) for the peaceful resolution of conflict (Mbaku, 1997, 2010).

Unfortunately for virtually all African countries, the decolonization project was undertaken reluctantly and opportunistically - the departing Europeans were reluctant to give up their hegemonic control of the African territories and the continent's freedom fighters were so eager to gain independence and take control of governance institutions that they were quite opportunistic in their approach to the decolonization process (Fatton, 1990; Crowder, 1987). As a consequence, they failed to fully and effectively transform the critical domains - that is, the political, administrative, and judicial foundations of the state-and "make them more suitable for governing post-independence African societies" (Mbaku, 2009: 40-41). During the colonial period, a significant level of state coercion was used to placate ethnic and religious groups and achieve peaceful coexistence. However, in the post-independence period, it was necessary that each African country avoid such a violent approach to the management of ethnic diversity and, instead, adopt an approach undergirded by or based on the rule of law.

During the colonial period in Africa, the critical domains were structured to serve the interests of the colonialists, Europeans resident in 
the colony (a population that included not only colonial officials and their families, but also settlers and colonists and their families) and the metropolitan economies (Mbaku, 2013a). These governance instruments were supposed to be completely dismantled and effectively reconstructed and reconstituted to produce institutional arrangements (and hence, governing processes) capable of adequately constraining the state and providing the wherewithal for the various population groups in each country to live together peacefully and maximize their values. Unfortunately, such democratic reforms were never undertaken, primarily because the groups that spearheaded the decolonization project did not favor the emergence of such democratic institutions in the postindependence society (Mbaku, 2013b; LeVine, 1997). These groups were (1) the colonial state; (2) European industrialists, farmers, planters, miners, and traders; and (3) a small group of highly educated and privileged indigenous African elites-the bulk of whom had been educated and trained in Europe, had lived in the colonizer's country for many years, and had adopted the colonizer's culture, customs and traditions, and to a great extent, worldview (Mbaku, 2009: 41). In addition to the fact that these three groups were not representative of the various ethnic and religious groups that populated each colony, they had not been elected by the people to represent them in the constitution and institution building process. Finally, the African elites either belonged to one dominant ethnocultural group or to a coalition of ethno-regional groups.

Perhaps more important is the fact that these three groups of actorsthe colonial state, indigenous elites, and the non-state European actorswho monopolized constitution making in the pre-independence period, did not have adequate information on "social, political and economic conditions then existing in most of the colony" nor did they fully understand the challenges that each country faced with respect to the conflicts arising from ethnocultural diversity (Mbaku, 2009: 41). Particularly disturbing is the fact that the constitution-writing committees in virtually all the African colonies failed to adequately consult each colony's relevant stakeholder groups or provide them with the wherewithal to participate fully and effectively in the process of choosing a constitution and developing institutions for post-independence governance (LeVine, 1964; Cowen, 1961).

Africans approached independence constitution making without taking cognizance of the dangers posed by unconstrained government, as well as the challenges posed by ethnocultural diversity. The top-down, elitedriven, non-participatory approach to constitution making produced institutional arrangements that have (1) failed to adequately constrain civil servants and politicians and prevent them from engaging in corruption, 
rent seeking and other forms of political opportunism; (2) not provided trusted and generally accepted mechanisms for the peaceful resolution of conflict and, as a consequence, during most of the post-independence period, individuals and groups have usually resorted to violence and destructive mobilization to improve their political and economic participation and minimize further marginalization; (3) not been able to enhance entrepreneurial activities, especially among historically marginalized and deprived groups (e.g., women, rural inhabitants, the urban poor, and ethnic and religious minorities); and (4) not safeguarded the people's fundamental rights, especially those of ethnic and religious minorities. In general, constitutional design in these divided societies did not provide governing systems that were capable of dealing effectively and fully with the challenges of ethnocultural conflict.

\subsection{AFRICA'S MOST IMPORTANT POLICY IMPERATIVES}

The fight against mass poverty and the struggle to improve levels of living for the people are the most important public policy priorities for virtually all countries in Africa today. An effective and sustainable fight against mass poverty must, of necessity, begin with the creation of wealth. Unfortunately, despite the recent upswing in economic activities in many African countries (Mbaku, 2014a), there cannot be sustained inclusive economic growth without peaceful coexistence. Pervasive political instability has encouraged capital flight, including the outward migration of skilled and highly educated human capital from these countries, and severely limited the inflow of foreign investment, and generally increased the costs of transacting in these economies (Crush, 2006; Tanner, 2005). Of course, some of this violent mobilization, such as that which occurred in Central African Republic, Liberia, Libya, Rwanda, Sierra Leone, South Sudan, Sudan (Republic of), and Somalia, has resulted in the deaths of hundreds of thousands of people, the destruction of a lot of property, and the creation of a major humanitarian crisis, which is likely to take many years to fully resolve.

Thus, providing each country with institutional arrangements that guarantee the rule of law and hence, provide effective structures for peaceful coexistence, is the most important prerequisite for the creation of the wealth needed to deal with poverty and improve living conditions. The development of such laws and institutions, however, must be undertaken through an inclusive and participatory process, that is, one that enhances the ability of all of each country's ethnocultural groups, 
including its minorities, to participate fully and effectively in the constitution-making process.

This research has shown that despite the major institutional reforms that have been undertaken throughout the continent since the demise of apartheid in 1994 and the subsequent collapse of many authoritarian regimes in the continent, effective management of ethnocultural diversity requires further deepening and institutionalization of those reforms so that each country can arm itself with institutional arrangements that guarantee the rule of law.

This study employs James M. Buchanan's (1994) constitutional political economy model, which provides great insight into how "societies formulate, select, and amend the rules that regulate their socio-political interaction," to show how each African country can provide itself with institutional arrangements that adequately protect the fundamental rights of all citizens, especially those of its ethnic and religious minorities (Mbaku, 2013a: 965; Brennan and Buchanan, 1985: 7). Interaction between individuals and between groups within a country is influenced significantly by the nature of the "rules" that exist in that country-such rules can be formal (e.g., a written constitution) or informal (e.g., custom and tradition). Adam Smith (1976 [1887]: 107) called these rules "laws and institutions." Brennan and Buchanan (1985) have argued that although rules or laws and institutions significantly enhance the ability of individuals to organize their lives and maximize their values-such values may include creating the wealth that they need to deal with poverty and material deprivation, or preserving their cultures and traditions, or getting married and raising a family-this is accomplished within a context in which they do not prevent other individuals or groups from accomplishing their own goals or maximizing their own values (Brennan and Buchanan, 1985: 14; Mbaku, 2013a: 966).

Thus, in arming citizens with the tools that they need to "organize their private lives and maximize their values" (Mbaku, 2013a: 966), rules also perform the "negative function of preventing disastrous harm" (Brennan and Buchanan, 1985: 14). Well-crafted rules, especially if they are designed through a democratic process - that is, one that enhances full and effective participation of all relevant stakeholders (which in divided societies, would necessarily include all ethnocultural groups) — can provide robust mechanisms for peaceful resolution of conflict and, at the same time, enhance the peaceful coexistence of groups within a country. They can also adequately constrain those who are empowered to govern the country and prevent them from behaving with impunity and violating the fundamental rights of citizens. 
Of course, we will also examine other approaches to governing divided societies and see how they can help African countries as they struggle to promote good governance and sustainable development. For example, we examine American republicanism to draw important lessons that can help the struggle in Africa to establish governing processes that adequately and fully protect the fundamental rights of minorities. Also, we examine the literature on comparative politics and comparative law to provide additional lessons for dealing with diversity in the African countries. In doing so, we shall pay particular attention to research carried out by scholars such as Dahl (1971, 1982-polyarchy and participation), Lijphart (1968b-consociational democracy), Horowitz (1993-democracy in divided societies), Lipset (1963 - theory of democracy), Bollen (1980, 1993-measurement of political democracy), Kymlicka (1996-group-differentiated citizenship), and Choudhry (2008-comparative constitutional law).

Guaranteeing peaceful coexistence in order to enhance wealth creation and human development in Africa requires a total reconstruction and reconstitution of the post-colonial state to provide institutional arrangements that guarantee the rule of law-implicit in the latter is that tyranny against minority groups by state- and non-state actors is minimized. This study shows that effective protection of the fundamental rights of minority groups within the country lies not just in a formal constitution, which may make provision for the protection of such rights, but in the nature of the governing process-whether, for example, there is, within such a governing process, the separation of powers with effective checks and balances. Consider, for example, the fact that while a country's constitution may contain a bill of rights, which specifically makes provision for the protection of the rights of minority ethnic and religious groups, such protection is not likely to be effective if there is no separation of powers, with checks and balances. Where, as in the case of the Francophone African countries, which adopted the French Constitution of 4 October 1958 as the blueprint for their post-independence laws and institutions, there is an imperial presidency which exercises significant power over the judiciary and the legislature, the rights of minorities are not likely to be protected even if the constitution contains a bill of rights (Fombad, 2005). The "framework of government" known as "separation of powers," guarantees that "no one person is able to gain absolute power and stand above the law. Each branch ... of government has some level of control or oversight over the actions of the other branches" (ABA, n.d.: 4).

The most effective way to protect the rights of minority groups is to make certain that "the law is superior, applies equally, is known and 
predictable, and is administered through a separation of powers" (Stein, 2009: 293). The key to effective protection of the rights of minorities is that the governance structure adopted by a country be one in which "no one in the government has so much power that they can act above the law" (ABA, n.d.: 4). During most of the post-independence period in a great deal of countries in Africa, the ruling elites-civil servants and politicians, including the heads-of-state-have acted with impunity, primarily because existing laws and institutions have either enhanced their ability to do so or have failed to adequately constrain them and prevent such opportunism. Most of the opportunistic behaviors, including corruption, rent seeking, violation of the fundamental rights of citizens, especially those of minority ethnic and religious groups, have been directed at garnering extra-legal income and privileges for the ruling elites (Mbaku, 2010).

Post-independence political opportunism, most of it designed to help ruling elites enrich themselves at the expense of the rest of the population, and also to ensure that they and the groups that they represent continue to monopolize political power, has had a significant negative impact on the management of ethnic and religious diversity - in fact, the activities of opportunistic elites seeking ways to enrich themselves and prolong their monopolization of political power have been responsible for a lot of the tyrannical behavior directed at minority ethnic and religious groups in many African countries during most of the post-independence period.

In the rest of this book, we explore ways in which African countries can minimize tyranny and other forms of impunity, including that directed at minorities, and enhance good governance and peaceful coexistence. In doing so, we shall draw on the experiences of many countries to illustrate the points that we make. For example, we shall draw on the experiences of the United States and Canada, which have been able to maintain fully functioning democratic systems for many years. The United States, like many countries in Africa, is a highlydivided society, consisting of many ethnocultural groups. Although it has faced some significant failures (e.g., slavery, the civil war, Jim Crow, including the lynching of African Americans and the exploitation of Native Americans-see, e.g., Curriden and Phillips, 1999; Lindsay, 2012), it has managed to make democracy work and in the process, it has also achieved significant advances in human development (Gustafson, 2011; Ackerman, 2011).

Canada has a rich history of dealing peacefully with ethnocultural diversity. The experiences of both the United States and Canada with diversity can provide African countries with important lessons on how to provide themselves with laws and institutions that can significantly 
enhance peaceful coexistence and provide the wherewithal for citizens to engage in productive activities to create the wealth that they need to fight poverty and improve national standards of living (Garcia, 2012).

Within Africa, we will draw on the experiences of several countries to illustrate our discussions on non-democratic approaches to constitution making. Specific emphasis will be placed on constitution making in the four colonies that united in 1910 to form the Union of South Africa (Cowen, 1961) and in the UN Trust Territory of Cameroons under French administration (LeVine, 1964). We note that constitution making in the French colonies in sub-Saharan Africa was especially troublesome, given the fact that all these colonies, except Guinea, gave up genuine constitutional discourse in favor of French president Charles de Gaulle's Constitution-that is, the Constitution of the French Fifth Republic (Nuenlist, Locher and Martin, 2010). The UN Trust Territory of Cameroons under French administration ${ }^{4}$ was one of the first colonies in sub-Saharan Africa to vote "yes" ("oui") to de Gaulle's Constitution (Schmidt, 2007). We will make extensive use of the experiences of Cameroon in constitution making and governance to illustrate our discussion on inappropriate approaches to the management of diversity. Reference will also be made to post-apartheid South Africa's constitutional experience, which provides important lessons in participatory and inclusive approaches to constitutional discourse (Arato, 2016; Lollini, 2011). The ultimate goal is to help the reader appreciate the importance of inclusion and participation in building institutions and governing processes that can significantly enhance peaceful coexistence and promote sustainable economic growth and development. The hope is that policymakers reading this book will benefit significantly from the analyses presented therein.

\section{NOTES}

1. Ojukwu, E., Col. (1969), The Ahiara Declaration: The Principles of the Biafran Revolution, 1 June, available at http://www.biafraland.com/Ahiara_declaration_1969.htm (last visited on 8 August 2014). The Republic of Biafra was the country formed by various groups in southeastern Nigeria, which had seceded from the federation in an effort to form their own sovereign state. See, e.g., Achebe, 2012 and Falola and Heaton, 2008.

2. Ojukwu, op. cit.

3. Ojukwu, E., Lt. Col. (1967), The Declaration of Independence, speech delivered on 30 May 1967, available at http://www.kwenu.com/biafra/declaration.htm (last visited on 6 August 2013).

4. French Cameroons, which was officially a UN Trust Territory under French administration, was technically not a colony. It, and other UN Trust Territories, however, were nevertheless administered as colonies. For more discussion on French Cameroons, see generally LeVine, Victor T. (1964), The Cameroons: From Mandate to Independence, Berkeley and Los Angeles, California, USA: The University of California Press. 